\title{
REDACTIONEEL
}

\section{Special issue on Education in (Professional) Legal Ethics, Emanuel van Dongen \& Jet Tigchelaar (eds.)}

\author{
Emanuel van Dongen \& Jet Tigchelaar*
}

\section{Abstract}

The theme of the special issue of Law and Method on Education in (Professional) Legal Ethics consists both of content-related as well as didactical-oriented contributions, of which most are written in the Dutch language and two are written in the English language. The content-related approaches show that in education in legal ethics use can be made of professional standards, constitutional principles as well as general ethical theories (such as utilitarianism, deontology, and virtue ethics). Because lawyers work with 'the law', broader or narrower conceptions of law (in relation to morality) also affect legal reasoning and are therefore relevant to education in professional legal ethics. However, these approaches are also put into perspective: the leap forward from moral reasoning based on abstract core values and ethical principles to morally correct action in concrete moral dilemmas in legal practice is a large one. Several solutions are proposed: I. teach ethics indirectly, stressing the importance of facts and of professional role consciousness, and of the importance of formal and informal respect for all concerned, as an essential part of the professional lawyers' role (Kaptein - written in English); II. use insights from social psychology to overcome barriers to actual ethical behaviour (Becker and Mackor); III. use dialogues about case studies that demonstrate different aspects of judicial ethics for judges (Brenninkmeijer\&Bish - written in English) or IV. give (to future governmental lawyers) context-sensitive bottom-up moral dilemmas to enhance realism, alertness and role resistance against opposing forces (Van Lochem). A relevant theme in the didactical approaches to legal ethics is the absence or limited practical professional experience law students have, so that, for example, conversation techniques based on personal experience have limited value. At university level, this can be remedied to some extent by reinforcing one's own experience, i.e. experiential learning, or by bringing the experiences of others into the classroom, for example with guest lecturers from the field, or by telling and discussing fictional or true stories (Van Dongen \& Tigchelaar). Education at university gives a good starting point for (professional)

* Dr. Emanuel van Dongen is Assistant Professor Private Law at the Molengraaff Institute for Private Law, researcher at the Utrecht Centre for Accountability and Liability Law and the Montaigne Centre for Rule of Law and Administration of Justice, Utrecht School of Law. Dr. Jet Tigchelaar, Assistent Professor Legal Theory, researcher at Utrecht Centre for European Research into Family Law, Utrecht School of Law. 
legal ethics, followed by post-academic legal ethics education and legal practice as lifelong learning school. A contribution with a focus on the notary (Waaijer) highlights the different approaches within this continuum.

Keywords: professional ethics.

Het thema van het special issue van Law and Method over Education in (Professional) Legal Ethics, kan in twee hoofdonderdelen uitgesplitst worden. Allereerst, in inhoudelijke benaderingen voor het onderwijs in professionele ethiek. Uit de bijdragen blijkt dat er kan worden aangehaakt bij professionele standaarden, zoals kernwaarden, die spanning kunnen opleveren met persoonlijke en maatschappelijke waarden. Ook zijn rechtsstatelijke principes en institutionele standaarden uitermate relevant als ethische context, waarbinnen juridische professionals opereren. Algemene ethische theorieën (zoals utilitarisme, deontologie en deugdethiek) zijn belangrijk, omdat zij criteria geven voor wat juist (handelen) is, die ook van toepassing zijn op het handelen in de rechtspraktijk van de juridische professional, zeker voor zover beroepsregels en rechtsregels handelings- en interpretatieruimte geven. Die ruimte wordt overigens ruimer of enger getrokken door bijvoorbeeld rechtsrealistische, natuurrechtelijke of rechtspositivistische opvattingen over wat recht is c.q. wie recht maakt. Toch wordt tegelijkertijd de inhoudelijke benadering gerelativeerd: de sprong van abstracte kernwaarden en ethische principes naar concrete morele dilemma's in de beroepspraktijk is groot. Bovendien wordt de omgang met 'feiten' onderschat. Hier worden verschillende conclusies aan verbonden: de een vindt de fasering van beroepsethisch onderwijs van belang (theorie aan de universiteit en concretere professionele standaarden en vragen daarna), de ander zoekt het in indirect en geïntegreerd onderwijs. Ook is leren moreel redeneren geen garantie voor daadwerkelijk ethisch handelen. Daarom verdienen sociaal-psychologische inzichten over drempels voor juist handelen aandacht in beroepsethisch onderwijs.

Bij de inhoudelijke benadering kan worden gekeken naar de gehele juridische professie, of iets meer ingezoomd worden op togadragers of - nog specifieker - op de eigen ethische problematiek van bepaalde juridische professies, zoals rechters (zie de bijdrage van Brenninkmeijer \& Bish), notarissen (zie de bijdrage van Waaijer), procederende en adviserende advocaten en bedrijfsjuristen, officieren van justitie, overheidsambtenaren (zie de bijdrage van Van Lochem) enz.). Ook worden soms rechtswetenschappers meegenomen, vanwege hun controlefunctie op de rechtsstatelijke instanties (zie de bijdrage van Mackor). Daarnaast bestaan er didactische benaderingen voor het onderwijs in professionele ethiek voor juristen. Hieronder vallen elementen die specifiek zijn voor onderwijs in professionele ethiek. Een relevant thema hierbij is de afwezigheid of beperkte praktijkervaring van studenten aan de universiteit, waardoor bijvoorbeeld gesprekstechnieken die van eigen ervaring uitgaan beperkte waarde hebben en hoe dit gecompenseerd kan worden. Dit kan gebeuren door de eigen ervaring te versterken in stages of door ervaringen van anderen de collegezaal binnen te brengen, bijvoorbeeld met gastdocenten uit de praktijk of door fictieve of waargebeurde verhalen te vertellen en te 
bespreken (zie bijv. de bijdrage van Brenninkmeijer en Bish, de bijdrage van Mackor en de bijdrage van Van Dongen \& Tigchelaar).

Boudewijn Waaijer ${ }^{1}$ behandelt de vraag of en hoe een bijdrage kan worden geleverd aan beroepsethisch handelen in het notariaat door educatie. Hij doet dat door een differentiatie aan te brengen in de opleidingseisen: die van rechtenstudent, van beginnend notarieel jurist en die voor notarieel jurist met een afgeronde beroepsopleiding. Levenslang leren dus. Als de grenzen van het juridisch domein ('gestolde ethiek' in wetgeving en rechtspraak) bereikt lijken te zijn, wint het belang van andere, meer algemene ethiek ('vloeibare ethiek'). Voor hulp of ten minste inspiratie verwijst hij onder meer naar de deugdethiek. Waaijer stelt dat studenten beroepsethische dilemma's zoveel mogelijk geïncorporeerd in de verschillende vakken moeten krijgen, dus idealiter niet uitsluitend, geconcentreerd in het vak Notariële ambtsuitoefening. Door aandacht voor de (ambts)ethiek door de gehele opleiding heen, kan het voortdurende bewustzijn over ambtsethiek bij studenten postvatten. Als onderwijsvorm noemt hij de Socratische gespreksmethode. Door georganiseerde reflectie op het notariskantoor zelf op de daar aanwezige rolmodellen, de 'voorbeeldige notarissen', kan de oogst later binnen worden gehaald. Nu immers, zullen de dilemma's onontkoombare praktijk vormen en zal echt kleur moeten worden bekend. Het gaat hier om het aloude model van overdracht van waarden van meester naar gezel.

Peter van Lochem ${ }^{2}$ schrijft over professioneel ethiekonderwijs voor de aankomende overheidsjurist, en maakt in zijn bijdrage een onderscheid tussen de aan de rechtsstaat ontleende (ambtelijke) beroepsethiek ('beroepsethiek van bovenaf'; bijv. kernwaardes in (ambtelijke) beroeps- en gedragscodes) en de overheidsinterne, contextuele beroepsethiek van overheidsjuristen ('beroepsethiek van onderop'). Hij noemt een realistische entree, gevoel voor tegenkracht en rolvastheid als redenen om bij het universitaire ethiekonderwijs voor de aankomend overheidsjurist de contextuele, overheidsinterne beroepsethiek als normatieve oriëntatie te nemen. Om dit gestalte te geven, dient de onderwijsinhoud gericht te zijn op de ontwikkeling van een empirie- en verantwoordingsgerichte attitude. Bij gerichtheid op de feiten en de verantwoording van het ambtelijk handelen mag worden verwacht dat de beoordeling van het betwiste ambtelijke handelen realistisch en proportioneel zal zijn. Ook de plaats in het onderwijs en de keuze van docenten kunnen bijdragen aan de contextgerichtheid van dit onderwijs. Gelet op de specifieke professie van de overheidsjurist ligt een afzonderlijk vak voor de hand. Omdat een groot deel van de studenten een juridische functie bij de overheid gaat vervullen, bepleit de auteur zo'n vak op te nemen in het algemene, voor alle studenten bestemde onderwijsprogramma.

Emanuel van Dongen en Jet Tigchelaar ${ }^{3}$ bespreken diverse inhoudelijke en didactische aanknopingspunten voor de integratie van professionele ethiek in de acade-

1 https://www.bjutijdschriften.nl/tijdschrift/lawandmethod/2021/03/lawandmethod-D-20-00011

2 https://www.bjutijdschriften.nl/tijdschrift/lawandmethod/2021/04/lawandmethod-D-21-00001

3 https://www.bjutijdschriften.nl/tijdschrift/lawandmethod/2021/06/lawandmethod-D-20-00012 
mische juridische opleiding. Volgens de auteurs gaat dat verder dan (enkel) het leren van gedragsregels, maar betreft deze ook de (kritisch-)ethische reflectie (op de professionele rol) van de jurist en ethische oordeelsvorming. Aanknopingspunten uit rechtstheoretische en onderwijskundige literatuur vragen om een curriculumbrede, stapsgewijze, inbedding met passende toetsing. Dit onderwijs dient idealiter een combinatie te zijn van afzonderlijke meta-juridische vakken over recht en ethiek, positiefrechtelijke vakken die ethische elementen bevatten, klinische training en specifieke vakken over beroeps- of professionele ethiek. Dit artikel bespreekt diverse methoden die kunnen worden gebruikt om het onderwijs vorm te geven en illustreert dit met enkele voorbeelden uit het Utrechts universitair juridisch onderwijs. Actieve participatie, reflectie en - idealiter - eigen ervaringen zijn daarbij van groot belang. Een aantal modellen uit niet-juridische disciplines kan behulpzaam zijn bij het bieden van structuur voor ethische reflectie, voor zover het morele sensitiviteit, ethische dilemma's en morele oordeelsvorming stimuleert. Leeractiviteiten en toetsing kan worden opgebouwd in het curriculum van kennis en begrip, naar competenties ten aanzien van ethische dilemma's en moreel oordelen.

Volgens Marcel Becker ${ }^{4}$ gaan ethiek en recht niet vanzelfsprekend samen, hoewel zij beide normatieve wetenschappen zijn. Ze verschillen echter door de verschillende grondslagen en accenten, waardoor ethiek niet vanzelfsprekend in rechtsregels kan worden uitgedrukt (en soms beter in bijvoorbeeld open geformuleerde codes en richtlijnen). Kennelijk heeft Becker te maken met studenten die moraal op een juridische wijze willen toeëigenen met voorbijgaan aan de beperkingen van het recht, want hij stelt dat 'een cursus ethiek voor juristen enkele legalistische tendensen moet overwinnen'. Toch is ethiek nodig in de gereedschapskist van de jurist, niet alleen vanwege de ethische reflectie op en verantwoording van bestaand recht, maar ook ter ondersteuning als juridische regels tekortschieten. Een interessante observatie is dat de toegenomen aandacht voor juridische beroepsethiek strategisch ingezet lijkt te worden, teneinde het vertrouwen van de samenleving te vergroten, terwijl ethiek tot intrinsieke waarden neigt. Een dergelijke instrumentele inzet van ethiek in het onderwijs ter verbreding van een eenzijdige juridische orientatie vindt Becker bezwaarlijk. Het kan gemakkelijk leiden tot moraliseren, terwijl academisch en ethisch onderwijs moet problematiseren en tot kritische normatieve reflectie moet uitnodigen als een juridische benadering tekortschiet. Ethische theorieën kunnen de student daarbij helpen, omdat zij morele ervaringen verhelderen. Sociaalwetenschappelijke inzichten tonen echter aan dat er mechanismen in ons (intuïtief en analytisch) denken zijn, die ons vaak onbewust (door cognitieve dissonantie) van goed gedrag kunnen afhouden. Bovendien vraagt gevoeligheid voor morele vragen om 'ervaring in de praktijk van het leven' - contact met praktijkervaringen is hierbij belangrijk.

Anne Ruth Mackor's ${ }^{5}$ inhoudelijke benadering betreft ethische theorieën als aspect van academische vorming die in de beroepsopleidingen minder aandacht krij- 
gen. Verder belicht zij de specifieke legitimatie van professionele ethiek van juristen vanwege de instandhouding van de rechtsstaat. Daarbij spelen onvermijdelijk spanningen tussen enerzijds waarden die de uitoefening van de professie mogelijk maken (zoals vertrouwelijkheid, vertrouwen en onafhankelijkheid), en anderzijds verantwoording en toezicht op die uitoefening een rol. Naast de kwestie van legitimatie, tracht zij studenten ook kritische benaderingen mee te geven. Eén daarvan belicht de paradoxale werking van New Public Management (NPM), die efficiëntie als professionele standaard heeft bevorderd, maar tegelijkertijd ook het integriteitsdenken heeft versterkt. Hiervoor zijn allerlei codes, kernwaarden, cursussen ethiek enzovoort in het leven geroepen, waarvan de effectiviteit - op grond van empirisch moreel-psychologisch onderzoek - betwijfeld kan worden of zelfs negatief is. Mackor wijst hier op het belang van sociaalwetenschappelijk inzichten om daarmee de beperkingen van (deugd)ethische reflectie te belichten. Mackor probeert naast kennis van en kritische reflectie op ethische theorieën, voor zover mogelijk praktijkervaring in te brengen (bijv. bij wetenschapsethiek in de onderzoeksmaster en voor promovendi).

Alex Brenninkmeijer en Didel Bish ${ }^{6}$ richten zich in hun bijdrage op het 'calibreren' van het morele kompas van (toekomstige) rechters, dat altijd nodig is voor juridisch redeneren. Voor dat 'didactisch' ijken van dat morele kompas van rechters onderscheiden de auteurs een soort dialoog aan de hand van casus op drie niveaus: de interne dialoog op microniveau, de dialoog op mesoniveau, die gericht is op consensus in raadkamer, en de dialoog op macroniveau, waarin de rol van de rechtspraak ten opzichte van de andere staatsmachten besproken wordt. De eerste casus betreft het oude verhaal van de corrupte rechter Sisamnes, wiens levend gevilde huid op de rechterszetel wordt gedrapeerd. Dit geldt niet alleen als waarschuwing voor rechters, dat hun privégedrag invloed heeft op een eerlijke procedure, maar is ook bedoeld als stimulans voor rechters om tegenwicht te bieden aan intervenierende krachten in de rechtspraak. Deze casus stimuleert dus het dialoog op microen macroniveau. De tweede casus gaat over het Toetsingsarrest van de Hoge Raad tijdens de Tweede Wereldoorlog, waarin werd overwogen dat 'een wet' (dus ook wetgeving van de bezetters) niet beoordeeld mag worden op 'innerlijke waarde of billijkheid' en niet getoetst mag worden aan een verdrag. Waarom werd dit overwogen? Brenninkmeijer en Bish menen dat er diverse verhaallijnen zijn die zich goed lenen voor een ethische dialoog op het meso-niveau over professionele opvattingen, maatschappelijke verwachtingen, morele motieven en emotionele drijfveren. De laatste casus gaat over de rol van de Raad van State in de Toeslagenaffaire. De dialoog hierover op alle drie de genoemde niveaus is nog volop gaande. Waarom maakte de Raad van State niet een meer eigen, onafhankelijke beoordeling van wetgeving en uitvoering, met een eigen afweging van de positie van de burger en het bestuur?

Hendrik Kaptein ${ }^{7}$ stelt zich op het standpunt dat legal ethics indirect kan worden onderwezen, - gezien het verzet tegen ethiek als een afzonderlijk en schijnbaar 
subjectief onderwerp. Volgens de auteur is discussie in termen van abstracte waarden en normen niet erg effectief voor ethisch handelen. Veeleer dient het onderwijs in legal ethics het belang van feiten te benadrukken (aangezien de grote meerderheid van juridische kwesties verband houdt met betwiste feiten), van professioneel rolbewustzijn en van het belang van formeel en informeel respect voor alle betrokkenen als essentieel onderdeel van professionele rollen. Deze indirecte benadering (van het onderwijzen van legal ethics) kan het beste worden geïntegreerd in het gehele juridische curriculum, in moot practices en legal clinics, - dat verduidelijkt wat het is om 'in de positie te verkeren van partijen die overgeleverd zijn aan juridische professionals' - en dat ook de perceptie biedt van de rechtsbedeling vanuit de ontvangende partijen. Basiskennis van forensische wetenschappen, argumentatie en retoriek kunnen ook hier goed van pas komen. Last but not least, moeten rechtendocenten het goede voorbeeld geven in hun professionele (en algemene) gedrag.

Uit de bijdragen komt vooralsnog geen one size fits all-model voor beroepsethisch onderwijs voor juristen naar voren, maar gezien de gelaagdheid van het thema, en de veelzijdigheid van de rechtspraktijk, was dat ook niet te verwachten. Wel worden inspirerende ideeën en ervaringen met enkele vaste ingrediënten en beperkende kaders gegeven en is het duidelijk dat professioneel ethisch onderwijs voor juristen in de rechtsstaat wezenlijke vragen aansnijdt, uitdagend is voor docent en student en vraagt om verankering in het academisch curriculum en in de rechtspraktijk van alledag. 